\title{
Quality Assessment of Gastropod Soup Powder Developed from Underutilized Chicoreus ramosus and Volegalea cochlidium ${ }^{\dagger}$
}

\section{R. Emilin Renitta ${ }^{1, *}$}

1 Department of Food Processing Technology, Karunya Institute of Technology and Sciences, Karunya Nagar 641114, Coimbatore, Tamil Nadu, India

* Correspondence: emilinrenitta@karunya.edu;

$\uparrow$ Presented at International e-Conference on Bioengineering for Health and Environment (ICBHE 2020)

Received: 5.07.2020; Revised: 10.07.2020; Accepted: 12.07.2020; Published: 15.07.2020

\begin{abstract}
Soup powder is one of the ready to serve product, which can be easily prepared. All classes of people enjoy the delicacy of soup. Nowadays, fish soup powders and soup tablets have become an acceptable food item. The development of value-added products by incorporating meat powder with other suitable ingredients could be easily acceptable to the people. So the demand for more convenient ready - to cook and ready - to eat packaged foods are constantly increasing. Keeping this in mind, meat soup powder from C. ramosus and Volegalea cochlidium were developed and packed in different packaging materials, and the shelf life period was assessed for 240 days storage.
\end{abstract}

Keywords: Gastropod; Chichoreus ramosus; Volegalea cochlidium; Shelf life Assessment; Soup powder; Value-added food products.

(C) 2020 by the authors. This article is an open-access article distributed under the terms and conditions of the Creative Commons Attribution (CC BY) license (https://creativecommons.org/licenses/by/4.0/).

\section{Funding}

This research received no external funding.

\section{Acknowledgments}

This research has no acknowledgment.

\section{Conflicts of Interest}

The authors declare no conflict of interest. 